\title{
Sciendo
}

DOI: $10.2478 /$ rjti-2020-0011

ROMANIAN JOURNAL

OF TRANSPORT INFRASTRUCTURE

\section{FREEZE/THAW RESISTANCE CLASSES OF CONCRETES}

Cristinel Moraru,Drd. Ing, S.C. HeidelbergCement Romania S.A., Bucharest, e-mail: cristinel.moraru@gmail.com

Apostu Adelina,Fiz. Dr., Technical University of Civil Engineering Bucharest,

Georgescu Dan,Prof. Dr. Ing., Technical University of Civil Engineering Buchares

\section{Rezumat}

Fenomenul de îngheț-dezgheţ prezintă un deosebit interes pentru domeniul infrastructurii transporturilor prin degradările pe care le produce acesta in structura elementelor de construcții. Specificul climatic din România pe de o parte și expunerea la medii agresive a elementelor de construcții în transporturi pe de altă parte, determină importanța studierii acestui fenomen, a modului acestuia de acțiune și propagare precum și a modalităților de prevenire și întreținere pentru asigurarea funcționalității construcţiilor din infrastructura transporturilor.

În prezent, în reglementările din România asigurarea durabilităţii se face, ca în majoritatea anexelor naţionale de aplicare a EN 206 [1] din Europa, printr-o abordare descriptivă (beton ,proiectat sa dureze”) făcându-se referire (cu statut de obligativitate) la o serie de cerinţe ale compoziției betonului (raport apă/ciment, dozaj minim ciment, aer antrenat, agregate rezistente la îngheţ-dezgheţ etc.) şi la rezistența la compresiune (clasa de rezistenta la compresiune a betonului) în funcție de încadrarea elementului într-o anumită clasă de expunere „X”.

Susținerea acestei abordări naționale descriptive s-a bazat pe analiza unui număr mare de rezultate obținute in cadrul unui program experimental complex desfășurat de UTCB, prin analiza rezultatelor obținute prin încercări de laborator asupra unor cimenturi „candidat” şi cimenturi „de referinţă” (având o buna comportare si tradiţională utilizare ) precum şi pe încercări/determinări ,in situ” pe elemente de construcții realizate cu ambele categorii de cimenturi și menținute in medii specifice.

La nivel european abordările de performanță în ceea ce privește durabilitatea au înregistrat progrese evidente. Punerea la punct a unor metode experimentale accelerate de laborator, stabilirea unor criterii de performanta, a unor clase de rezistenta la diferite acțiuni ale mediului si legătura între acestea si clasele de expunere la diferite acțiuni ale mediului au fost punctul de pornire al cercetărilor experimentale ale căror rezultate vor fi prezentate in acest articol.

Astfel coroborat cu aceste abordări moderne se va prezenta o analiză asupra rezultatelor experimentale obținute în cadrul unor cercetări asupra rezistentei la înghețdezgheț a betoanelor preparate cu diferite tipuri de cimenturi, realizate în colaborare cu colectivul laboratorului Departamentului de Construcții din Beton Armat, Universitatea Tehnică de Construcții București precum și propuneri de încadrare in diferite clase de rezistenta la îngheţ-dezgheţ. 


\section{Cuvinte cheie: ciment, beton, durabilitate, îngheț-dezgheț}

\section{Abstract}

The freeze/thaw phenomenon is of interest for the field of transport infrastructure through the degradations it produces in the structure of construction elements. The climatic specificity of Romania on the one hand and the exposure to aggressive environments of construction elements in transport on the other hand, determine the importance of studying this phenomenon, its mode of action/propagation and also prevention and maintenance to ensure the functionality of buildings in transport infrastructure.

Currently, in the Romanian regulations [*], the assurance of sustainability is done, as in most national annexes for the application of EN 206 [1] in Europe, by a descriptive approach (concrete "designed to last") referring to (with mandatory status) a series of requirements of the concrete composition (water / cement ratio, minimum cement dosage, entrained air, freeze/thaw resistant aggregates, etc.) and to the compressive strength (concrete compressive strength class) in depending on the classification of the element in a certain exposure class "X".

The support of this descriptive national approach was based on the analysis of a large number of results obtained in a complex experimental program carried out by Technical University of Civil Engineering Bucharest, by analyzing the results obtained by laboratory tests on "candidate" cements and cements "reference" (having a good behavior and traditional use) as well as "in situ" tests/determinations on construction elements made with both categories of cements and maintained in specific environments.

At European level, performance approaches to sustainability have made clear progress. The development of accelerated laboratory experimental methods, the establishment of performance criteria, classes of resistance to various environmental actions and the link between them and the classes of exposure to various environmental actions were the starting point for experimental research whose results will be presented in this article.

Thus, in conjunction with these modern approaches, an analysis will be presented on the experimental results obtained in research on freeze/thaw resistance to different types of cements, carried out in collaboration with the laboratory of the Reinforced Concrete Structures Department, Technical University of Civil Engineering Bucharest and proposals for classification in different classes of freeze/thaw resistance.

Keywords: cement, concrete, durability, freeze/thaw

\section{INTRODUCTION}

Ensuring the durability of concrete by establishing levels (criteria) of performance depending on the place of use of concrete (materialized by the class of resistance to actions of the environment "RX") is an absolutely necessary step forward given that, even at European level, reached a certain "degree of 
saturation" in terms of acceptance of new types of "candidate" cement in different exposure classes by the (current) descriptive method.

This article aims to present the concept of freeze/thaw resistance class ("RXF") and proposals for the classification of concrete prepared with different types of cements in freeze/thaw resistance classes.

The European-accepted freeze/thaw resistance test methods are complemented by proposals for classification criteria, depending on the results obtained, in different XF exposure classes. Their application largely reflects the real-time behavior of concrete subjected to freeze/thaw.

The test methods used at European level are:

- CEN/TS 12390-9 - Tests on hardened concrete - Part 9: Freezethaw resistance of concrete. Scaling;

- CEN/TR 15177 - Testing the freeze-thaw resistance of concrete Internal structural damage.

The types of cement covered by this research report can be considered as new, "candidate" cements for which there is no relevant national experience in use. In addition, CEM II/A-M cements with limestone in their composition represent cements for which at European level the level of knowledge and acceptance in regulations remains quite limited.

SR EN 206 [1] shows changes in W/C ratios, cement dosages and concrete grades compared to SR EN 206-1: 2002. XF2 is the only exposure class in which the composition is the same.

\section{DEFINING FREEZE/THAW RESISTANCE CLASSES}

The freeze/thaw resistance of concrete is defined by the maximum number of freeze-thaw cycles that a concrete element can withstand, without suffering degradation that could affect its operating conditions. By introducing the concept of freeze/thaw resistance classes, a method of ensuring the durability of concrete is proposed, establishing some criteria of performance in the form of environmental resistance class "RXF".

The national annex of SR EN 206-1: 2002, SR 13510 [2], in force at the time of the experimental research, provides for the four classes of freeze/thaw exposure the limit values presented in table 1 . 
ROMANIAN JOURNAL

OF TRANSPORT INFRASTRUCTURE

Cristinel Moraru, Apostu Adelina, Dan Georgescu

Freeze/thaw resistance classes of concretes

Table 1. Recommended limit values for concrete composition and properties

\begin{tabular}{|c|c|c|c|c|c|c|}
\hline & \multicolumn{6}{|c|}{ Exposure classes } \\
\hline & \multicolumn{6}{|c|}{ Freeze/thaw attack } \\
\hline & XF1 & \multicolumn{2}{|c|}{ XF2 } & \multicolumn{2}{|c|}{ XF3 } & \multirow{2}{*}{$\begin{array}{c}\text { XF4 } \\
0,50 a\end{array}$} \\
\hline $\begin{array}{l}\text { Maximum } \\
\text { water / } \\
\text { cement ratio }\end{array}$ & 0,50 & $0,55 a$ & 0,50 & $0,55 a$ & 0,50 & \\
\hline $\begin{array}{l}\text { Minimum } \\
\text { strength class }\end{array}$ & $\mathrm{C} 25 / 30$ & $\mathrm{C} 25 / 30$ & C35/45 & $\mathrm{C} 25 / 30$ & $\mathrm{C} 35 / 45$ & $\mathrm{C} 30 / 37$ \\
\hline $\begin{array}{l}\text { Minimum } \\
\text { dosage of } \\
\text { cement } \\
(\mathrm{kg} / \mathrm{m} 3)\end{array}$ & 300 & 300 & 320 & 300 & 320 & 340 \\
\hline $\begin{array}{l}\text { Minimum } \\
\text { entrained air } \\
\text { content }(\%)\end{array}$ & - & $\mathrm{a}$ & - & $\mathrm{a}$ & - & $\mathrm{a}$ \\
\hline $\begin{array}{l}\text { Other } \\
\text { conditions }\end{array}$ & \multicolumn{5}{|c|}{ Freeze/thaw resistant units SR EN 12620} & d \\
\hline \multicolumn{7}{|c|}{$\begin{array}{l}\text { a) The entrained air content is determined according to the maximum size of the granule. If the concrete } \\
\text { does not contain intentionally entrained air, then the performance of the concrete must be measured } \\
\text { according to an appropriate test method, compared to a concrete for which the freeze/thaw resistance has } \\
\text { been established for the appropriate exposure class. } \\
\text { d) In case of exposure in marine areas, cements resistant to the action of seawater will be used. }\end{array}$} \\
\hline
\end{tabular}

There are also recommendations for choosing the limit values of the composition and properties of the concrete according to the exposure class according to SR EN $206+$ A1: 2017 (table 2) [1]. 
ROMANIAN JOURNAL

OF TRANSPORT INFRASTRUCTURE

Cristinel Moraru, Apostu Adelina, Dan Georgescu

Freeze/thaw resistance classes of concretes

Table 2. Recommended limit values for concrete composition and properties

\begin{tabular}{|c|c|c|c|c|}
\hline & \multicolumn{4}{|c|}{ Freeze/thaw attack } \\
\hline & XF1 & XF2 & XF3 & XF4 \\
\hline $\begin{array}{l}\text { Maximum water / } \\
\text { cement ratio }\end{array}$ & 0,55 & 0,55 & 0,50 & 0,45 \\
\hline $\begin{array}{l}\text { Minimum strength } \\
\text { class }\end{array}$ & C30/37 & $\mathrm{C} 25 / 30$ & C30/37 & C30/37 \\
\hline $\begin{array}{l}\text { Minimum dosage of } \\
\text { cement }(\mathrm{kg} / \mathrm{m} 3)\end{array}$ & 300 & 300 & 320 & 340 \\
\hline $\begin{array}{l}\text { Minimum entrained } \\
\text { air content }(\%)\end{array}$ & - & $4,0 \mathrm{a}$ & $4,0 \mathrm{a}$ & 4,0a \\
\hline Other conditions & \multicolumn{4}{|c|}{$\begin{array}{l}\text { Aggregates according to EN } 12620 \text { with sufficient } \\
\text { freeze/thaw resistance }\end{array}$} \\
\hline \multicolumn{5}{|c|}{$\begin{array}{l}\text { a If the concrete does not contain entrained air, then the performance of the concrete must be measured using } \\
\text { an appropriate test method, by comparison with a concrete, for which the freeze/thaw resistance for the } \\
\text { appropriate exposure class has been established. }\end{array}$} \\
\hline
\end{tabular}

$\rightarrow$ Criteria proposed by Technical University of Civil Engineering Bucharest - UTCB and accepted by Ministry of Public Works, Development and Administration - MDRAP, slab test method:

1. Exposure class XF1 (cement dosage $320 \mathrm{~kg} \mathrm{~m}^{3}$ and $\mathrm{W} / \mathrm{C}$ ratio $=0.5$ )

The amount of scaled material must be less than $1.3 \mathrm{~kg} / \mathrm{m}^{2}$ after 56 cycles.

2. XF2 exposure class (cement dosage $320 \mathrm{~kg} / \mathrm{m3}$ and $\mathrm{W} / \mathrm{C}$ ratio $=0.5$, entrained air)

The amount of scaled material must be less than $1.3 \mathrm{~kg} / \mathrm{m}^{2}$ after 56 cycles.

3. XF3 exposure class (cement dosage $320 \mathrm{~kg} / \mathrm{m3}$ and $\mathrm{W} / \mathrm{C}$ ratio $=0.5$ )

The amount of scaled material must be less than $1 \mathrm{Kg} / \mathrm{m}^{2}$ after 56 cycles.

$\rightarrow$ European evaluation criteria for exfoliation, slab test method:

4. Exposure class XF4 (cement dosage $320 \mathrm{~kg} / \mathrm{m}^{3}$ and $\mathrm{W} / \mathrm{C}$ ratio $=0.5$, entrained air)

The amount of scaled material must be less than $1 \mathrm{Kg} / \mathrm{m}^{2}$ after 56 freezethaw cycles.

There is a proposal to introduce in EN 206 [1] the RXF freeze/thaw resistance classes - Chapter 4.2, Table 3 and Table F.1 in Annex F, respectively. 
ROMANIAN JOURNAL

OF TRANSPORT INFRASTRUCTURE

Cristinel Moraru, Apostu Adelina, Dan Georgescu

Freeze/thaw resistance classes of concretes

Table 3. Exposure resistance classes, applicable limit values and standards, slab test method [3]

\begin{tabular}{|l|c|c|}
\hline \multicolumn{3}{|c|}{ RXF freeze/thaw resistance classes } \\
\hline & RXF0,5 & RXF1 \\
\hline Limit values, $\mathrm{kg} / \mathrm{m}^{2}$ & 0,5 & 1,0 \\
\hline $\begin{array}{l}\text { Applicable } \\
\text { standards }\end{array}$ & \multicolumn{2}{|c|}{ CEN/TS $12390-9$} \\
CEN/TR15177
\end{tabular}

- RXF0.5 assumes that $\mathrm{m}_{56}<0.5 \mathrm{~kg} / \mathrm{m}^{2}$

- RXF1.0 assumes that $\mathrm{m}_{56}<1.0 \mathrm{~kg} / \mathrm{m}^{2}$

- $\mathrm{m}_{\mathrm{n}}$ - represents the mass of scaled material in $\mathrm{kg} / \mathrm{m}^{2}$ at the surface of the concrete specimen, after $n$ freeze/thaw cycles (in this case $n=56$ cycles)

There are proposals to supplement EC2. Table 4 presents the initial proposal of EC2, including the notations regarding the freeze/thaw resistance classes.

Table 4. Proposal to complete EC2

\begin{tabular}{|c|c|}
\hline \multicolumn{2}{|c|}{ Concrete degradation } \\
\hline Freeze/thaw resistance class & \\
\hline $\begin{array}{c}\text { RXF } \\
\text { (Medium) }\end{array}$ & $\begin{array}{c}\text { RXF } \\
\text { (High) }\end{array}$ \\
\hline $\begin{array}{l}\text { The definition of the class } \\
10 \% \text { (respectively } 2 \% \text { ) prob } \\
\text { loss at the surface }\left[\mathrm{kg} / \mathrm{m}^{2}\right]\end{array}$ & $\begin{array}{l}\text { posure to XF4, with a } \\
\text { ding the concrete }\end{array}$ \\
\hline 10 & 2 \\
\hline
\end{tabular}

The severity of the climate can be defined in locally valid provisions, based on the zonal climate, regarding frost cycles and extreme temperatures.

Table 5 presents a variant of classification of freeze/thaw resistance, including classification into specific exposure classes. An important aspect of this proposed variant is the link between exposure classes and freeze/thaw resistance classes. 
Table 5. Classification of concrete in freeze/thaw exposure classes

\begin{tabular}{|c|l|l|}
\hline \multirow{2}{*}{ Exposure class } & \multicolumn{2}{|c|}{ Freeze/thaw resistance class } \\
\cline { 2 - 3 } & \multicolumn{1}{|c|}{$\begin{array}{c}\text { Moderate frost } \\
\text { climate }\end{array}$} & Severe frost climate \\
\hline XF1 & $\mathrm{RF}^{1}$ & $\mathrm{RF} 1$ \\
\hline $\mathrm{XF} 2$ & $\mathrm{RF} 1$ & $\mathrm{RF} 0,2$ \\
\hline $\mathrm{XF} 3$ & $\mathrm{RF} 1$ & $\mathrm{RF} 0,2$ \\
\hline XF4 & $\mathrm{RF} 0,2$ & $\mathrm{RF} 0,2$ \\
\hline \multicolumn{2}{|c|}{ In the moderate frost climate the test environment may be fresh water } \\
\hline
\end{tabular}

- RF0.2 assumes that $\mathrm{m}_{56}<0.2 \mathrm{~kg} / \mathrm{m}^{2}$

- RF1.0 assumes that $\mathrm{m}_{56}<1.0 \mathrm{~kg} / \mathrm{m}^{2}$

- $\mathrm{m}_{\mathrm{n}}$ - represents the mass of scaled material in $\mathrm{kg} / \mathrm{m}^{2}$ at the surface of the concrete specimen, after $n$ freeze/thaw cycles (in this case $n=56$ cycles)

A problem with the proper classification for the four XF classes is that there are two different scenarios, one with salt (chlorides) and one without and possibly different degradation mechanisms.

Proposals can be made to supplement EC2 with the notions of freeze/thaw resistance classes, for example in Table 6 a proposal under discussion for the use of 2 climate classes is presented [4].

Table 6. Concrete damage, resistance classes allowed for XF exposure classes

\begin{tabular}{|c|c|c|}
\hline \multicolumn{3}{|c|}{ Freezing - thawing action } \\
\hline $\begin{array}{c}\text { Exposure } \\
\text { class } \\
\text { EC }\end{array}$ & Minimum allowable freeze/thaw resistance classes \\
\cline { 2 - 3 } & Severe frost climate & Light frost climate ${ }^{1}$ \\
\hline XF1 & RXF12 & RXF12 \\
\hline XF2 & RXF12 & RXF12 \\
\hline XF3 & RXF0,5 & RXF1,0 \\
\hline XF4 & RXF0,5 & RXF1,0 \\
\hline $\begin{array}{l}\text { The mild frost climate can be defined in locally valid provisions, based on the zonal } \\
\text { climate, regarding frost cycles and extreme temperatures. }\end{array}$ \\
\hline
\end{tabular}

- RXF12 is covered by DtS (Deemed to Satisfy) and the descriptive text from EN 206 for XF1 and XF2

- RXF0.5 assumes that $\mathrm{m}_{56}<0.5 \mathrm{~kg} / \mathrm{m}^{2}$ 
- RXF1.0 assumes that $\mathrm{m}_{56}<1.0 \mathrm{~kg} / \mathrm{m}^{2}$

and condition valid for all RXF classes $\mathrm{m}_{56} / \mathrm{m}_{28}<2$

RXF0.5 and RXF1.0 can be defined with an alternative DtS (Deemed to Satisfy) classification that completes the test requirement.

Another proposal for introduction into EC2 presented in CEN TC250/SC2/WG1/TG10 N0045 [5] for the classification of freeze/thaw resistance according to exposure classes is presented in Table 7.

\begin{tabular}{|l|l|l|}
\hline \multicolumn{3}{|c|}{ Concrete damage } \\
\hline \multicolumn{3}{|c|}{ Freeze/thaw resistance } \\
\hline $\begin{array}{l}\text { RFW H } \\
\text { (High resistance) }\end{array}$ & $\begin{array}{l}\text { RFW M } \\
\text { (Medium resistance) }\end{array}$ & $\begin{array}{l}\text { RFW L } \\
\text { (Low resistance) }\end{array}$ \\
\hline $\begin{array}{l}\text { RFD H } \\
\text { (High resistance) }\end{array}$ & $\begin{array}{l}\text { RFD M } \\
\text { (Medium resistance) }\end{array}$ & $\begin{array}{l}\text { RFD L } \\
\text { (Low resistance) }\end{array}$ \\
\hline $\begin{array}{l}\text { 2 } \text { Tested according to the slab Test method CEN / TS 12390-9 with water } \\
{ }^{3} \text { Tested according to the slab Test method CEN / TS 12390 9 with salt solution }\end{array}$ \\
\hline
\end{tabular}

Adequate freeze/thaw resistance only for moderately saturated concretes (exposure classes XF1 and XF2) can be achieved by using a composite concrete according to EN 206. Adequate durability against the freeze-thaw action of concrete exposed to moisture (exposure classes XF3 and XF4) can be assumed by selecting the appropriate RF class according to Table 7 regarding the climatic conditions at the location and the projected service life "P" of the structure.

Table 7. Freeze-thaw resistance classes (proposal for tables 4.2 and 4.5 of EC2, only the freeze-thaw part)

\begin{tabular}{|c|c|c|}
\hline & \multicolumn{2}{|c|}{ Exposure class } \\
\hline & XF3 & XF4 \\
\hline $\begin{array}{l}\text { Mild winters }{ }^{1} \\
\text { Moderate winters }^{2} \text { and } \mathrm{P}<100\end{array}$ & RFW L & RFD L \\
\hline $\begin{array}{l}\text { Moderate winters }{ }^{2} \text { and } \\
\mathrm{P} \geq 100 \\
\text { Severe winters }{ }^{3} \text { and } \mathrm{P}<100\end{array}$ & RFW M & RFD M \\
\hline $\begin{array}{llll}\text { Severe } & \text { winters } & 3 & \text { and } \\
P \geq 100 & & & \end{array}$ & RFW H & RFD H \\
\hline
\end{tabular}


Definitions of mild, moderate and severe winters can be discussed and adjusted. Romania has a temperate continental climate with a severe specificity regarding the freeze/thaw cycles, which in winter reach twice a day.

It would be better to use the maximum real value of exfoliation in the designation of the resistance class, as there may be further discussions on the corresponding values for the different winter climates.

\section{Proposal for criteria:}

- $\quad$ RFW L and RFD L: $\mathrm{m}_{56}<2,0 \mathrm{~kg} / \mathrm{m}^{2}, \mathrm{~m}_{56} / \mathrm{m}_{28}<2$ or $\mathrm{m}_{110}<2,0 \mathrm{~kg} / \mathrm{m}^{2}$

- $\quad$ RFW M and RFD M: $\mathrm{m}_{56}<1,0 \mathrm{~kg} / \mathrm{m}^{2}$ or $\mathrm{m}_{110}<1,0 \mathrm{~kg} / \mathrm{m}^{2}$

- RFW H and RFD H: $\mathrm{m}_{56}<0,5 \mathrm{~kg} / \mathrm{m}^{2}$ or $\mathrm{m}_{110}<0,5 \mathrm{~kg} / \mathrm{m}^{2}$

- RFW represents the frost resistance of the samples kept in water;

- RFD represents the frost resistance of the samples kept in deicing solution;

The above criteria are valid for the initial testing of a concrete composition. When tested for control or in existing structures, the maximum exfoliation values may be increased by $20 \%$. Considering the difficulties and the multitude of factors that intervene in the determination of some characteristics of the concrete in-situ, this value of $20 \%$ has an informative character and must be correlated with other characteristics of the concrete.

The dynamism of methods and criteria based on scientific and technical progress must be considered.

\section{EXPERIMENTAL RESEARCH}

\subsection{Materials and Methods}

The experimental research presented was based on 3 cements (in fact two types CEM II/A-M(S-LL) 32,5R and CEM II/A-S 32,5R) with different compositional characteristics. The CEM 1 and CEM 2 (first type, candidate) are two Portland composite cements CEM II/A-M(S-LL) 32,5R, containing different percentages of slag and limestone admixtures. In order to see the influence of the different percentages of slag and limestone additions, 2 cements of this type were tested, in which other influencing factors that could intervene, for example the composition, fineness and hydraulic potential of the clinker were kept constant. The choice of this candidate cement was made taking into 
account, the fact that even if it already is a favorable international experience regarding the use of CEM II/A-M(S-LL) cements, there is not a such experience in Romania.

CEM 3 (second type) being considered the reference cement, is a Portland cement with slag CEM II/A-S 32,5R, whose qualities have been confirmed over the years in Romania.

In order to be able to compare more effectively the prepared concretes with the three cements, the same compositions were used, cement dosage 320 $\mathrm{kg} / \mathrm{m}^{3}$ and $\mathrm{W} / \mathrm{C}=0.5$, the tests being carried out in accordance with CEN / TS 12390-9. [6]

The determination of freeze/thaw resistance was made in accordance with the Romanian standard SR 3518. [7] The destructive method according to this standard determines the decrease of the compressive strength of the test specimens tested in freeze/thaw compared to the control specimens (made at the same time, of the same concrete and preserved until the test under the same conditions as the specimens to be tested). The simplicity of this method results from the lack of a connection between the exposure concrete classes defined according to SR EN 206 and the resistance of concrete to freeze/thaw aggressivity. It also cannot be applied for thawing conditions with de-icing agents.

In Europe the most common test methods are performed according to the CEN/TS 12390-9 standard [6]. This standard describes a reference method (slab test) and two alternative test methods (cube test and CF/CDF test). The introduction of the CEN / TS 12390-9 standard states that when new component materials or compositions are used, they must be tested in accordance with the methods presented.

No correlations are established between the results obtained by applying these three methods.

In the experimental research whose results will be presented in this article, the freeze/thaw concrete resistance was determined using the slab test method. The principle of the method is presented below:

\section{$\rightarrow$ Slab test (reference method)}

Freeze/thaw resistance is assessed by measuring the mass of scaled concrete on the exposed surface after 56 freeze/thaw cycles. 
The test requires four samples, one in four cubes. The first day after casting the cubes are kept in molds and protected against drying by using a polyethylene film at an air temperature of $(20 \pm 2){ }^{\circ} \mathrm{C}$.

After this time the cubes are stripped and placed in water at a temperature of $(20 \pm 2)^{\circ} \mathrm{C}$.

At the age of 7 days, the cubes are removed from the water and placed in a climatic chamber until the beginning of the test.

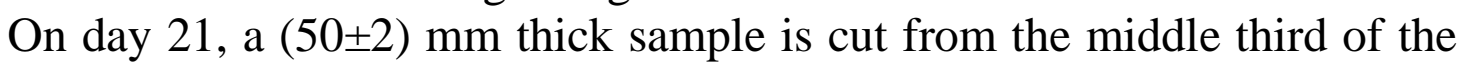
cube.

After cutting, the sample is washed and reintroduced into the climatic chamber.

At the age of $(25 \pm 1)$ days of the concrete, the support of the sample is made.

At the age of 28 days, water is poured, $3 \mathrm{~mm}$ deep, at a temperature of 20 $2^{0} \mathrm{C}$ on the surface of the concrete sample, and is maintained at this level for $(72 \pm 2) \mathrm{h}$. The test starts at the age of 31 days of the concrete, respecting the freeze-thaw cycles. is applied:

After $(7 \pm 1)(14 \pm 1)(28 \pm 1)(42 \pm 1)$ and 56 cycles the following procedure

- Collect the scaled material from the surface, brush the exposed concrete surface;

- Pour enough water to a depth of $3 \mathrm{~mm}(67 \mathrm{ml})$

- Place the sample in the refrigerator

- Then determine the mass of scaled material, dried at a constant mass $(110 \pm 10){ }^{\circ} \mathrm{C}$.

\subsection{Classification of concretes in freeze/thaw resistance classes depending on the experimental results}

\subsubsection{Results obtained in the laboratory}

Tests for the determination of freeze/thaw resistance were carried out in accordance with the CEN/TS 12390-9 standard. [6]

Tables 8 (freeze/thaw without de-icing agents) and 9 (freeze/thaw with de-icing agents) show the results recorded for freeze/thaw resistance and classification into freeze/thaw resistance classes by types of cement. 
ROMANIAN JOURNAL

OF TRANSPORT INFRASTRUCTURE

Cristinel Moraru, Apostu Adelina, Dan Georgescu

Freeze/thaw resistance classes of concretes

Table 8. Results recorded for freeze/thaw resistance and classification in freeze/thaw resistance classes by types of cement

\begin{tabular}{|c|c|c|c|c|c|}
\hline Cement type & \begin{tabular}{|l|} 
Cement \\
dosage \\
$\left(\mathrm{kg} / \mathbf{m}^{3}\right)$
\end{tabular} & $\mathrm{W} / \mathrm{C}$ & $\begin{array}{c}\text { Compressive } \\
\text { strength } \\
\left(\mathrm{N} / \mathrm{mm}^{2}\right) \\
\end{array}$ & $\begin{array}{c}\mathrm{Sn}, \\
\mathrm{kg} / \mathrm{m}^{2} \\
(56 \text { cycles })\end{array}$ & \begin{tabular}{|c|} 
Freeze/thaw \\
resistance \\
classes
\end{tabular} \\
\hline $\begin{array}{c}\text { CEM II/A-S 32,5R - CEM } \\
3\end{array}$ & 320 & 0,5 & 41,93 & 0,04 & $\mathrm{RXF} 0,2$ \\
\hline $\begin{array}{l}\text { CEM II/A-M(S-LL) } \\
\text { 32,5R - CEM } 1\end{array}$ & 320 & 0,5 & 39,12 & 0,90 & RXF1 \\
\hline $\begin{array}{l}\text { CEM II/A-M(S-LL) } \\
\text { 32,5R - CEM } 2\end{array}$ & 320 & 0,5 & 41,11 & 0,89 & RXF1 \\
\hline
\end{tabular}

Table 9. Results recorded for freeze/thaw resistance and de-icing agents and classification of freeze/thaw resistance classes by type of cement

\begin{tabular}{|c|c|c|c|c|c|}
\hline Cement type & $\begin{array}{l}\text { Cement } \\
\text { dosage } \\
\left(\mathbf{k g} / \mathbf{m}^{3}\right)\end{array}$ & W/C & $\begin{array}{c}\text { Compressive } \\
\text { strength } \\
\left(\mathrm{N} / \mathbf{m m}^{2}\right)\end{array}$ & $\begin{array}{c}\mathrm{Sn}, \\
\mathrm{kg} / \mathrm{m}^{2} \\
(56 \text { cycles })\end{array}$ & \begin{tabular}{|c} 
Freeze/thaw \\
resistance \\
classes
\end{tabular} \\
\hline $\begin{array}{c}\text { CEM II/A-S 32,5R - CEM } \\
3 \\
\end{array}$ & 320 & 0,5 & 27,22 & 0,06 & RXF0,2 \\
\hline $\begin{array}{c}\text { CEM II/A-M(S-LL) } \\
\text { 32,5R - CEM } 1\end{array}$ & 320 & 0,5 & 38,73 & 0,78 & RXF1 \\
\hline $\begin{array}{c}\text { CEM II/A-M(S-LL) } \\
\text { 32,5R - CEM } 2\end{array}$ & 320 & 0,5 & 39,18 & 0,61 & RXF1 \\
\hline
\end{tabular}

The influences of the concrete composition on this determination must be considered, including the quality of the aggregates, which decisively influences the compressive strength.

Even until the current introduction of environmental resistance classes, these tests are useful to be able to recommend/promote certain cements with different applications.

Existing variants for the classification of freeze/thaw resistance according to exposure classes are presented below. 


\subsubsection{Framing results obtained in existing evaluation criteria in the $\mathbf{E U}$}

Concretes prepared with the three types of cements meet the criteria for classification in XF exposure classes both for the European evaluation criterion and for the criterion proposed by UTCB and accepted by MDRAP:

Table 10. Criteria for classification in XF exposure classes

\begin{tabular}{|c|c|c|c|c|}
\hline Exposure & XF1 & XF2 & XF3 & XF4 \\
\hline Metod & $\begin{array}{c}\text { Slab } \\
\text { test** }\end{array}$ & $\begin{array}{c}\text { Slab } \\
\text { test }^{* *}\end{array}$ & $\begin{array}{c}\text { Slab } \\
\text { test*** }\end{array}$ & $\begin{array}{c}\text { Slab } \\
\text { test* }^{*}\end{array}$ \\
\hline CEM II/A-M (CEM 1) & $\mathbf{X}$ & $\mathbf{X}$ & $\mathbf{X}$ & $\mathbf{X}$ \\
\hline CEM II/A-M (CEM 2) & $\mathbf{X}$ & $\mathbf{X}$ & $\mathbf{X}$ & $\mathbf{X}$ \\
\hline CEM II/A-S (CEM 3) & $\mathrm{X}$ & $\mathrm{X}$ & $\mathbf{X}$ & $\mathbf{X}$ \\
\hline
\end{tabular}

$\mathrm{X}=$ criterion met,

*) the European criterion

**) criteria proposed by UTCB and endorsed by MDRAP

The criteria for assessing the exfoliation strength of concrete after freezethaw cycles in the presence of $3 \% \mathrm{NaCl}$, according to the Boras method presented in the Swedish standard SS 137244 [8] are:

- Very good concrete: $\mathrm{m}_{56}<0,1 \mathrm{~kg} / \mathrm{m}^{2}$

- Good concrete: $\mathrm{m}_{56}<0,2 \mathrm{~kg} / \mathrm{m}^{2}$ or

$$
\begin{aligned}
& \mathrm{m}_{56}<0,5 \mathrm{~kg} / \mathrm{m}^{2} \text { and } \mathrm{m}_{56} / \mathrm{m}_{28}<2 \text { or } \\
& \mathrm{m}_{112}<0,5 \mathrm{~kg} / \mathrm{m}^{2}
\end{aligned}
$$

- Acceptable concrete: $\mathrm{m}_{56}<1 \mathrm{~kg} / \mathrm{m}^{2}$ and $\mathrm{m}_{56} / \mathrm{m}_{28}<2$ or

$$
\mathrm{m}_{112}<1 \mathrm{~kg} / \mathrm{m}^{2}
$$

- Unacceptable concrete: $\mathrm{m}_{56}>1 \mathrm{~kg} / \mathrm{m}^{2}$ and $\mathrm{m}_{56} / \mathrm{m}_{28}>2$ or

$$
\mathrm{m}_{112}>1 \mathrm{~kg} / \mathrm{m}^{2}
$$

In accordance with the criteria set out above, Tables 11 and 12 show the classification of the concrete according to the results obtained experimentally. 
Table 11. Evaluation of the concrete durability after freeze-thaw cycles

\begin{tabular}{|l|l|l|l|}
\hline Cement type & $\begin{array}{l}\mathrm{m}_{28,} \\
\mathrm{~kg} / \mathrm{m}^{2}\end{array}$ & $\begin{array}{l}\mathrm{m}_{56,} \\
\mathrm{~kg} / \mathrm{m}^{2}\end{array}$ & Evaluation criteria \\
\hline $\begin{array}{l}\text { CEM II/A-M(S-LL) 32,5R - } \\
\text { CEM 1 }\end{array}$ & 0,39 & 0,90 & Acceptable concrete \\
\hline $\begin{array}{l}\text { CEM II/A-M(S-LL) 32,5R - } \\
\text { CEM 2 }\end{array}$ & 0,38 & 0,89 & Acceptable concrete \\
\hline CEM II/A-S 32,5R - CEM 3 & 0,03 & 0,04 & Very good concrete \\
\hline
\end{tabular}

Table 12. Evaluation of the concrete durability after freeze-thaw cycles with de-icing agents

\begin{tabular}{|l|l|l|l|}
\hline Cement type & $\begin{array}{l}\mathrm{m}_{28,} \\
\mathrm{~kg} / \mathrm{m}^{2}\end{array}$ & $\begin{array}{l}\mathrm{m}_{56,} \\
\mathrm{~kg} / \mathrm{m}^{2}\end{array}$ & Evaluation criteria \\
\hline $\begin{array}{l}\text { CEM II/A-M(S-LL) 32,5R - CEM } \\
1\end{array}$ & 0,23 & 0,78 & Acceptable concrete \\
\hline $\begin{array}{l}\text { CEM II/A-M(S-LL) 32,5R - CEM } \\
2\end{array}$ & 0,28 & 0,61 & Acceptable concrete \\
\hline CEM II/A-S 32,5R - CEM 3 & 0,04 & 0,06 & Very good concrete \\
\hline
\end{tabular}

Table 13 presents a variant of the freeze/thaw resistance classification, including the classification in the specific exposure classes, according to the classification presented in Table 6 . The definitions of moderate / severe climates are still under discussion. 
Table 13. Classification of concrete in freeze-thaw exposure classes

\begin{tabular}{|c|l|l|}
\hline \multirow{2}{*}{$\begin{array}{c}\text { Exposure } \\
\text { Class }\end{array}$} & \multicolumn{2}{|c|}{ Freeze/thaw resistance classes } \\
\cline { 2 - 3 } & \multicolumn{1}{|c|}{ Moderate frost climate } & \multicolumn{1}{c|}{ Severe frost climate } \\
\hline \multirow{4}{*}{ XF1 } & RF1 & RF1 \\
\cline { 2 - 3 } & II/A-S 32,5R - CEM 3 & II/A-S 32,5R - CEM 3 \\
\cline { 2 - 3 } & II/A-M(S-LL) 32,5R - CEM 1 & II/A-M(S-LL) 32,5R - CEM 1 \\
\cline { 2 - 3 } & II/A-M(S-LL) 32,5R - CEM 2 & II/A-M(S-LL) 32,5R - CEM 2 \\
\cline { 2 - 3 } XF2 & RF1 & RF0,2 \\
\cline { 2 - 3 } & II/A-S 32,5R - CEM 3 & II/A-S 32,5R - CEM 3 \\
\cline { 2 - 3 } & II/A-M(S-LL) 32,5R - CEM 1 & \\
\cline { 2 - 3 } & II/A-M(S-LL) 32,5R - CEM 2 & \\
\cline { 2 - 3 } XF3 & RF1 & RF0,2 \\
\cline { 2 - 3 } & II/A-S 32,5R - CEM 3 & II/A-S 32,5R - CEM 3 \\
\cline { 2 - 3 } & II/A-M(S-LL) 32,5R - CEM 1 & \\
\cline { 2 - 3 } & II/A-M(S-LL) 32,5R - CEM 2 & \\
\cline { 2 - 3 } XF4 & RF0,2 & RF0,2 \\
\cline { 2 - 3 } & II/A-S 32,5R - CEM 3 & II/A-S 32,5R - CEM 3 \\
\cline { 2 - 3 } & &
\end{tabular}

Using the proposal to complete EC2 in Table 7 we can formulate evaluation criteria for concrete exposed to freeze/thaw presented in Tables 14 and 15 .

Table 14. Evaluation criteria for concrete exposed to freeze-thaw, samples kept in water

\begin{tabular}{|c|c|c|}
\hline & \multicolumn{2}{|c|}{ Exposure Class } \\
\hline & XF3 & XF4 \\
\hline \multirow{4}{*}{$\begin{array}{l}\text { Mild } \\
\text { winters }{ }^{1} \\
\text { Moderate } \\
\text { winters and } \\
\mathrm{P}<100\end{array}$} & RFW L* & RFD L* \\
\hline & $\mathrm{m}_{56}<2,0 \mathrm{~kg} / \mathrm{m}^{2}$ & $\mathrm{~m}_{56}<2,0 \mathrm{~kg} / \mathrm{m}^{2}$ \\
\hline & II/A-M(S-LL) 32,5R - CEM 1 & II/A-M(S-LL) 32,5R - CEM 1 \\
\hline & $\begin{array}{c}\text { II/A-M(S-LL) 32,5R - CEM } 2 \\
\text { II/A-S 32,5R - CEM } 3\end{array}$ & $\begin{array}{c}\text { II/A-M(S-LL) 32,5R - CEM } 2 \\
\text { II/A-S 32,5R - CEM } 3\end{array}$ \\
\hline \multirow{5}{*}{$\begin{array}{l}\text { Moderate } \\
\text { winters }{ }^{2} \\
\text { and } \\
P \geq 100 \\
\text { Severe } \\
\text { winters }\end{array}$} & RFW M & RFD M \\
\hline & $\mathrm{m}_{56}<1,0 \mathrm{~kg} / \mathrm{m}^{2}$ & $\mathrm{~m}_{56}<1,0 \mathrm{~kg} / \mathrm{m}^{2}$ \\
\hline & II/A-M(S-LL) 32,5R - CEM 1 & II/A-M(S-LL) 32,5R - CEM 1 \\
\hline & II/A-M(S-LL) 32,5R - CEM 2 & II/A-M(S-LL) 32,5R - CEM 2 \\
\hline & II/A-S 32,5R - CEM 3 & II/A-S 32,5R - CEM 3 \\
\hline
\end{tabular}


ROMANIAN JOURNAL

OF TRANSPORT INFRASTRUCTURE

Cristinel Moraru, Apostu Adelina, Dan Georgescu

Freeze/thaw resistance classes of concretes

\begin{tabular}{|c|c|c|}
\hline \\
\hline \multirow{3}{*}{$\begin{array}{l}\text { Severe } \\
\text { winters } \\
\text { and } \\
P \geq 100\end{array}$} & RFW H & \multirow{2}{*}{$\begin{array}{c}\text { RFD H } \\
\mathrm{m}_{56}<0,5 \mathrm{~kg} / \mathrm{m}^{2}\end{array}$} \\
\hline & $m_{56}<0,5 \mathrm{~kg} / \mathrm{m}^{2}$ & \\
\hline & II/A-S 32,5R - CEM 3 & II/A-S 32,5R - CEM 3 \\
\hline
\end{tabular}

*) The ratio $\mathrm{m}_{56} / \mathrm{m}_{28}<2$ is an additional proposal for RFW L and RFD L. and in this case, $\mathrm{m}_{56} / \mathrm{m}_{28}<2$ for CEM II/A-S and $\mathrm{m}_{56} / \mathrm{m}_{28}>2$ for CEM II/A-M.

Table 15. Evaluation criteria for concrete exposed to freeze-thaw with defrosting agents

\begin{tabular}{|l|l|l|}
\hline Cement type & $\begin{array}{l}\mathrm{m}_{56}, \\
\mathrm{~kg} / \mathrm{m}^{2}\end{array}$ & $\begin{array}{l}\text { Evaluation } \\
\text { criteria }\end{array}$ \\
\hline CEM II/A-M(S-LL) 32,5R - CEM 1 & 0,78 & $\begin{array}{l}\text { RFW L, RFD L } \\
\text { RFW M, RFD M }\end{array}$ \\
\hline CEM II/A-M(S-LL) 32,5R - CEM 2 & 0,61 & $\begin{array}{l}\text { RFW L, RFD L } \\
\text { RFW M, RFD M }\end{array}$ \\
\hline CEM II/A-S 32,5R - CEM 3 & 0,06 & RFW H, RFD H \\
\hline
\end{tabular}

The test results allow to obtain recommendations regarding the correct design of an exfoliation-resistant concrete. The durability of concrete exposed to freeze-thaw in the presence of defrost salts can be ensured by a low water/cement ratio.

Exfoliation of the concrete surface is a very complicated phenomenon due to the large number of independent factors that produce it.

\section{CONCLUSIONS}

The inclusion of concrete in freeze/thaw resistance classes using the results of European test methods and the criteria proposed in the technical committees for the development of European standards in the field, is the novelty of this research. 
In order to be able to compare more effectively the prepared concretes with the three types of cements, the same compositions were used, cement dosage $320 \mathrm{~kg} / \mathrm{m}^{3}$ and $\mathrm{W} / \mathrm{C}=0.5$, the tests being carried out in accordance with CEN / TS 12390-9. [6]

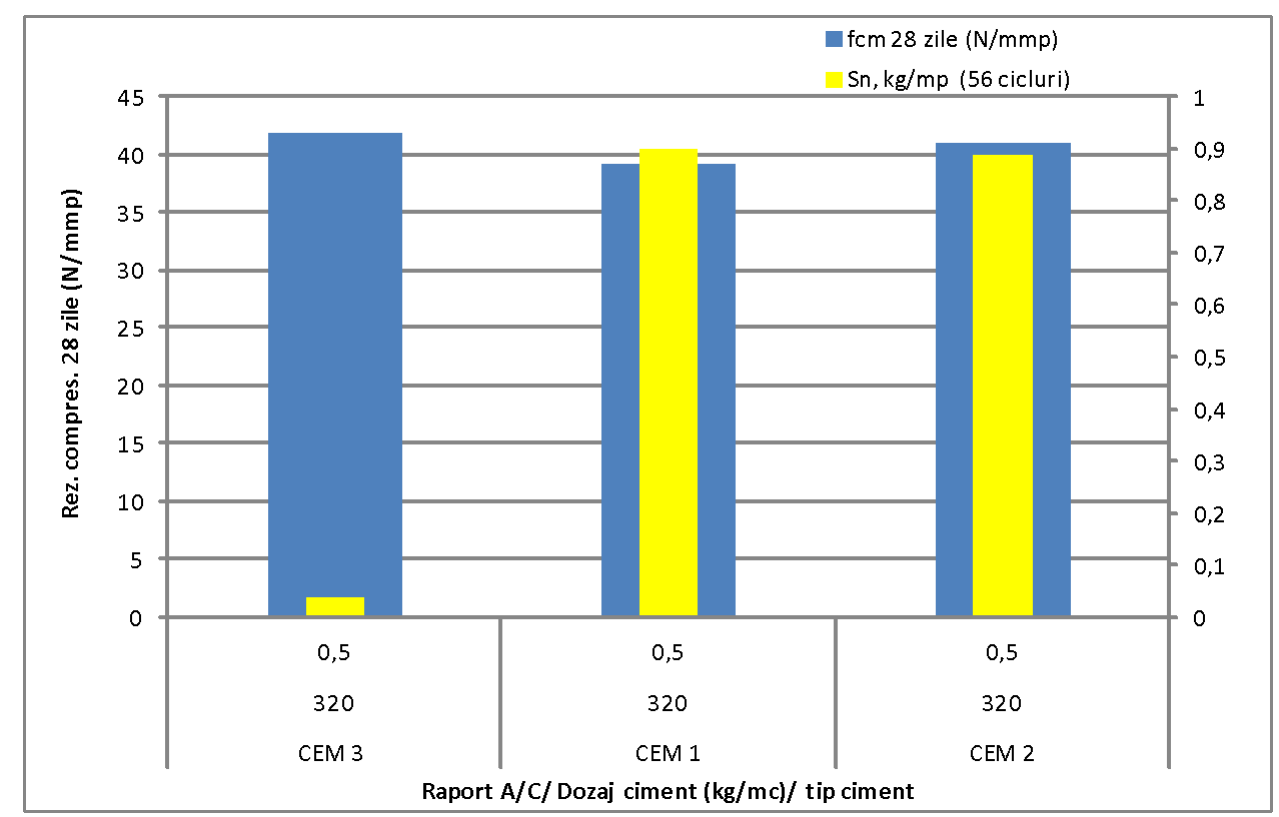

Figure 1. Comparison of the masses of the scaled material after 56 freeze-thaw cycles, without thawing agents

The Sn values obtained in the case of concretes prepared with CEM II/A$\mathrm{S}$ are lower than those obtained for concretes prepared with the two CEM II/A$\mathrm{M}$ cements, all falling within the evaluation criteria for freeze/thaw resistance by scalation.

Using the experimental results obtained and the performance criteria presented, CEM type II/A-S cement can be used in all exposure classes for lifetimes of 50 and 100 years. For a service life of 200 years, determinations of the amount of scaled concrete after 112 freeze-thaw cycles are required for exposure classes XF3 and XF4.

The test results allow to obtain recommendations regarding the correct design of an exfoliation-resistant concrete.

As a direction of future research, it is necessary to carry out several tests on different concrete mixtures with water/cement ratios between 0.6 and 0.4 , in order to observe the classification of concretes prepared with different types of cements in the freeze/thaw resistance classes. 


\section{ROMANIAN JOURNAL \\ OF TRANSPORT INFRASTRUCTURE}

Cristinel Moraru, Apostu Adelina, Dan Georgescu

Freeze/thaw resistance classes of concretes

\section{REFERENCES}

[1]. SR EN $206+\mathrm{A} 1: 2017$, Beton. Specificație, performanță, producție si conformitate.

[2]. SR 13510:2006-Beton. Partea 1: Specificaţie, performanţă, producţie and conformitate.

$[3]$.

[4].

STEINAR LEIVESTAD - "Durability, Concrete, Environment and Sustainability în the Eurocodes", 02.05.2019, Standard Norge.

$[5]$.

\section{CEN/TC250/SC2/WG1 N479}

SR EN 1992-1-1:2004 Eurocod 2: Proiectarea structurilor de beton; Partea 1-1: Reguli generale and reguli pentru clădiri.

$[6]$.

CEN/TS 12390-9:2016 Testing hardened concrete - Part 9: freeze-thaw resistance with de-icing salts.

$[7]$.

SR 3518:2009, Incercări pe betoane. Determinarea rezistenţei la îngheț-dezgheț prin măsurarea variaţiei rezistenţei la compresiune şi/sau modulului de elasticitate dinamic relative.

$[8]$.

SS 137244:2005 - Concrete testing - Hardened concrete - Scaling at freezing (Standard Swedish). 